\title{
Modeling the carbon cycle of the municipal solid waste management system for urban metabolism
}

\author{
Chuanbin Zhou ${ }^{\mathrm{a}, *}$, Heping Huang ${ }^{\mathrm{a}, \mathrm{b}}$, Aixin Cao ${ }^{\mathrm{a}}$, Wanying $\mathrm{Xu}^{\mathrm{a}}$ \\ a State Key Laboratory of Urban and Region Ecology, Research Center for Eco- Environmental Science, Chinese Academy of Sciences, Shuangqing Road 18, \\ Haidian District, Beijing 100085, China \\ ${ }^{\mathrm{b}}$ Institute of Poyang Lake Eco-Economics, Jiangxi University of Finance and Economics, East Shuanggang Road 169, Nanchang 330013, China
}

\section{A R T I C L E I N F O}

\section{Article history:}

Available online 17 December 2014

\section{Keywords:}

Carbon cycle

Carbon stock

Model

Urban metabolism

Municipal solid waste

\begin{abstract}
A B S T R A C T
Municipal solid waste management is one of the key subsystems of urban metabolism, which significantly impacts urban carbon cycles. A conceptual model for analyzing the carbon cycle of the municipal solid waste management system was established based on the theory of urban metabolism with regard to urban carbon cycling. The model includes horizontal fluxes, vertical fluxes and carbon stocks of the waste managing processes such as waste collection, transportation, treatment and disposal. The current carbon cycling of the municipal solid waste management system and two other scenarios were analyzed using a Jingmen City case study. The results indicate that the input horizontal flux in municipal solid waste between 1989 and 2004 was $293.47 \mathrm{Gg}$. Among all of the considered scenarios, the landfill formed the largest carbon stocks; incineration showed the largest vertical fluxes of carbon dioxide, and source separation and integrated technologies decreased carbon emissions by adding new carbon sources to the urban system. Improving municipal solid waste management using techniques, such as waste minimization, source separation, recycling, technical innovations of incineration, compost and digestion of organic waste, landfill mining, etc., could impact the urban carbon cycle by reducing carbon emissions.
\end{abstract}

(C) 2014 Elsevier B.V. All rights reserved.

\section{Introduction}

The concept of urban metabolism was put forward by Wolman (1965), and Kennedy further defined urban metabolism as the summation of social economic and technological processes that result in urban development, energy production and waste emission (Kennedy et al., 2007). Urban systems play an important role in the global carbon cycle, and the carbon dioxide emissions of urban systems are typically approximately $80 \%$ of the total carbon dioxide emission (Svirejeva-Hopkins and Schellnhuber, 2006, 2008). In an urban system, carbon is input in terms of food, fossil fuel, goods, etc., and it is processed and transformed within human society; a portion of the carbon is then stocked in the urban

Abbreviations: MSW, municipal solid waste; MSWM, municipal solid waste management; GHGs, greenhouse gases; LFGs, landfill gases; LF, scenario 1/landfill; INC, scenario 2/incineration; SIT, scenario 3/source separation and integrated technologies; IPCC, Intergovernmental Panel on Climate Change; CDM, clean development mechanism.

* Corresponding author. Tel.: +86 1062849147 ; fax: +86 1062943807

E-mail address: cbzhou@rcees.ac.cn (C. Zhou). system, while the other part is output as solid waste, wastewater and waste gases (Lebel, 2005; Chen et al., 2011a,b; Chen and Chen, 2012; Li et al., 2013). The municipal solid waste management (MSWM) system is not only a subsystem of the urban system (including production, consumption, logistics and recovery), but also a self-organized social-economic-natural complex ecosystem that has environmental impacts on rivers, lakes, underground water, soil, air, plants and the landscape (Zhou et al., 2011).

The MSWM system is one of the major sources of carbon emissions in an urban system. Almost all of the municipal solid waste management processes produce carbon emissions in the form of carbon dioxide and methane, including processes of collection, transportation, compost, digestion, incineration and landfill. Solid waste was listed as an independent chapter in the Guidelines for National Greenhouse Gas Inventories by the Intergovernmental Panel on Climate Change (IPCC, 2007). Between 1990 and 2005, the global methane emissions from the solid waste in landfills were estimated to have increased by approximately $12 \%$, from 706 to $792 \mathrm{MtCO}_{2} \mathrm{e}$, ranking fifth among all non- $\mathrm{CO}_{2}$ emission sources (USEPA, 2012). The municipal solid waste treatment projects aimed at reducing carbon emissions were active in the global carbon exchange 
market under the framework of the clean development mechanism (CDM).

More and more attention has been directed toward the carbon cycling of MSWM, and some progresses have been made in this field in the recent years. The generation and immigration of landfill gases (LFGs) and the controlling methods were first studied (Chai et al., 2010), and then carbon emissions were widely considered with respect to source separation, waste collection routine, treatment technologies (e.g., landfill, incineration, compost, anaerobic digestion of organic fraction of MSW, etc.) and decision-making tools (Calabrn, 2009; Bastin and Longden, 2009; Mühle et al., 2010; Fdez-Güelfo et al., 2012). The municipal solid waste (MSW) greenhouse gas (GHG) emissions and carbon footprint were chosen as important indicators for evaluating the efficiency of the MSWM system in previous studies (Khoo et al., 2010; Couth and Trois, 2010). Multiple methods, such as the life cycle analysis (LCA), the GHG inventories of the IPCC and the first-order decomposition model (FOD) have been applied for carbon emission analysis, using the data from statistics, laboratory testing and field studies (Kumar et al., 2004).

Many studies have recognized the importance of the modeling of the MSWM system, for example, Beigle et al. (2008) analyzed the models of municipal solid waste generation, and Kollikkathara et al. (2010) and Gunalay et al. (2012) analyzed the economic and policy making models of municipal solid waste management, and Pires et al. (2011) summarized multiple systems analysis models and tools that were used in the waste management practice in European countries. But in the view of urban metabolism and urban carbon cycle, systemic models for analyzing the carbon cycling of the whole MSWM system (including the carbon fluxes, flows, stocks and their relationship, etc.) were rarely discussed in previous reports. In this research, we try to establish a systemic and conceptual model based on the theory of urban metabolism and the urban carbon cycle. And then we model the carbon fluxes and carbon stocks of the MSWM system in the studied case, Jingmen City in central China, using integrated methods of simulation, lab analysis and field studies. This work may be helpful for assessing, planning, optimizing and making policies for better municipal solid waste management systems.

\section{Materials and methods}

\subsection{Conceptual carbon cycle model of the MSWM system}

Galina (2008) described the spatial structure of the urban system as consisting of the urban sprawl and the urban footprint. The carbon cycle in the urban system includes carbon fluxes (vertical fluxes and horizontal fluxes) and carbon stocks (pools). The vertical fluxes are the carbon that migrated and released to the atmosphere, hydrosphere and lithosphere, while the horizontal fluxes are the carbon that exchanged from the urban sprawl areas and urban footprint areas (crops, forests, wastes). Based on the conceptual model of the urban carbon cycle, a carbon cycle model of the MSWM system was established (see Fig. 1).

\subsubsection{Horizontal fluxes}

The horizontal fluxes consist of the carbon exchanges between the urban system and the municipal solid waste management system, including the following elements: (i) direct horizontal fluxes, consisting of transportation of the municipal solid waste generated from the urban inhabitants to the MSWM system, transportation of the compost produced from organic waste to urban green land, and transportation of the regenerated materials (paper, plastic, rubber, concrete, etc.); and (ii) indirect horizontal fluxes, consisting of the fossil fuel consumed for collecting, transporting, treating and disposing of the MSW.

\subsubsection{Vertical fluxes}

The vertical fluxes include the carbon exchanges between the MSWM system and the atmosphere, hydrosphere and lithosphere: (i) direct vertical fluxes, covering methane and carbon dioxide emissions through the anaerobic digestion and aerobic biodegradation, the carbon dioxide emission through the thermal decomposition, and the leachate outlet to the water body or immigration to soil; and (ii) indirect vertical fluxes, consisting of carbon emissions from burning fossil fuel for collection, transportation, treatment and disposal of the MSW.

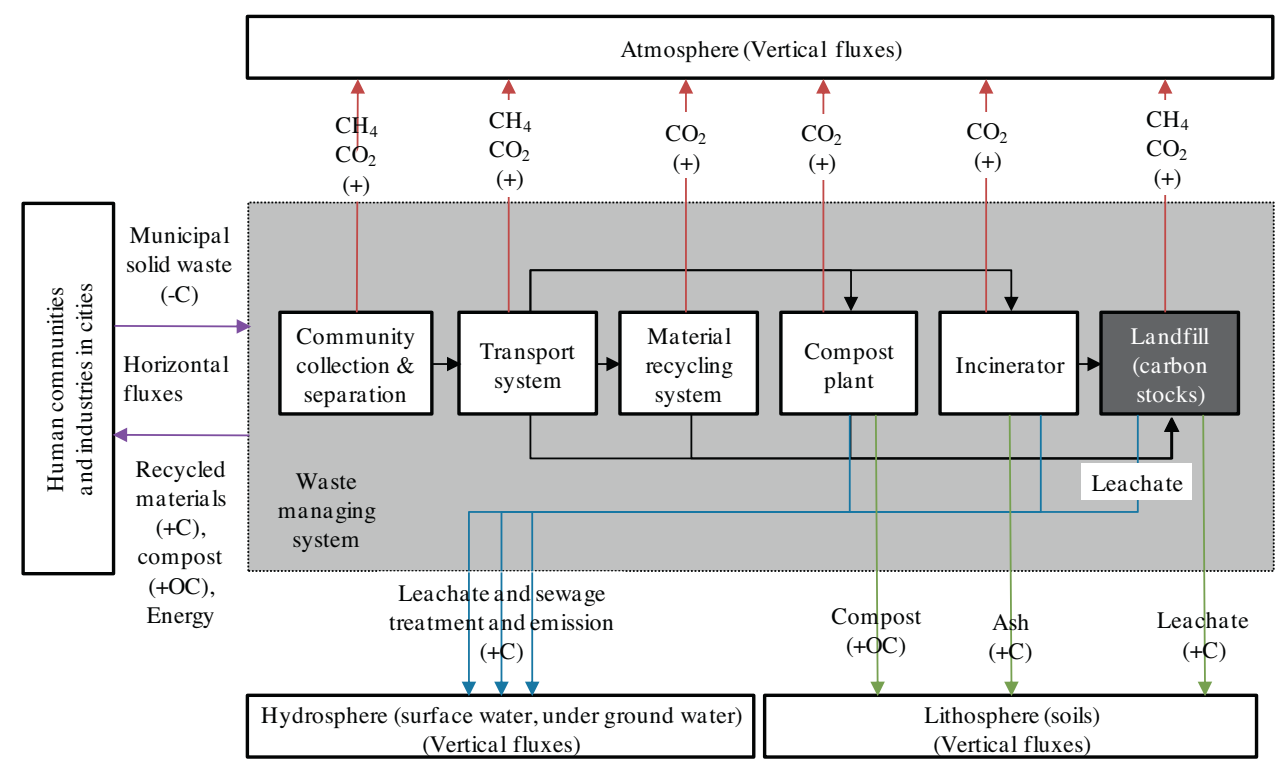

Urban ecosystem

Fig. 1. Conceptual model of the carbon cycle of the municipal solid waste management system in terms of urban metabolism. 


\subsubsection{Carbon stocks (pools)}

This consists of fixed and stocked carbon in the MSWM system, including stored waste within the old landfills and dumpsites, storage of incinerated ashes, and temporary storage of the recycled materials that cannot be recovered due to technical or economic infeasibilities. The carbon stocks can be transformed into new carbon sources or carbon sinks, depending on the conditions. Soil-like materials and other buried materials could be recycled and retransported to the urban system after landfill mining, and they could then generate new horizontal carbon fluxes. Bad operation of MSW carbon stocks (treatment facilities) can result in unexpected immigration of pollutants to the river, underground water, air and soil and the generation of new vertical carbon fluxes.

\subsection{Description of the studied case}

Our study is based on the conceptual carbon cycle model of the MSWM system (Section 2.1), and it is based on the parameters of Jingmen City, which is a typical medium-sized city located in central China that was taken as our study case for analysis of vertical fluxes, horizontal fluxes and carbon stocks. The MSWM system in Jingmen City is a simple and single stream system. MSW was collected without source separation, and it was then transported to the only Yingchun landfill for final disposal. This landfill was constructed in 1989, closed in 2004, and served 0.4 million inhabitants. It was a basic, unsanitary landfill that covered an area of 11.3 ha. The site was built sloping northwards, giving it a dustpanlike appearance. The annual amount of disposed municipal solid waste increased from 36.5 thousand tons in 1989 to 154.8 thousand tons in 2004. Currently, this site produces waste leachate of approximately $80 \mathrm{~m}^{3}$ per day, accompanied by uncontrolled emissions of landfill gases. We studied the carbon cycle of the MSWM system of Jingmen City during the period from 1989 to 2012. The carbon fluxes were calculated based on the MSW input from 1989 to 2004, the carbon fluxes through LFGs were simulated from 1989 to 2004 and 2005 to 2012 (the period of post-closure care), and the carbon stocks were tested in 2012. The total quantity of MSW generated by Jingmen city was kept growing to 434.0 thousand tons in 2012, and the MSW was transported to another sanitary landfill site for final disposal.

\subsection{Methods for determining horizontal carbon fluxes}

1) Horizontal carbon fluxes are considered in terms of MSW input: the data sources were the statistics collected by the local MSWM authority (Environmental Sanitation Bureau), which is in charge of weighing and recording the quantity of municipal solid waste in the Yingchun landfill every day (the MSW is weighed before disposal). The local MSWM authority also completed composition analysis of the municipal solid waste every year, and the MSW was classified into categories including kitchen food waste, stone and ash, paper, textile, plastic and rubber, wood, metal and glass. The moisture content and the total carbon content of the various categories of municipal solid waste are shown in Table 1, and the carbon fluxes were calculated using the Eq. (1):

$H C_{\text {waste }}=\sum M_{i} \cdot c_{\text {component } . i j} \cdot\left(1-c_{\text {moisture } . j}\right) \cdot c_{\text {carbon } . j}$

where $H C_{\text {waste }}$ is the horizontal carbon flux of the municipal solid waste input; $M$ is the weight of municipal solid waste production per year; $c_{\text {component }}$ is the annual average ratio of the different waste component (dry weight basis) data obtained from annual sampling and analysis from the local waste management authority; $c_{\text {moisture }}$ is the typical moisture content of different waste components; $c_{\text {carbon }}$ is the typical carbon content of various waste components; $i$ is the studied year; and $j$ is the component
Table 1

Typical moisture and carbon contents of various municipal solid waste components (Tchobanoglous, 2000).

\begin{tabular}{llcc}
\hline Composition & Carbon (\%, dry basis) & Moisture (\%) & Ash (\%) \\
\hline Food waste & 48.0 & 70 & 5.0 \\
Dirt, ash, etc. & 26.3 & 8 & 68.0 \\
Paper & 43.5 & 6 & 6.0 \\
Textiles & 55.0 & 10 & 2.5 \\
Plastics & 60.0 & 2 & 10.0 \\
Wood & 49.5 & 20 & 1.5 \\
Metals & 4.5 & 3 & 90.5 \\
Glass & 0.5 & 2 & 98.9 \\
\hline
\end{tabular}

of municipal solid waste, classified as food waste, stone and ash, paper, textiles, plastics, wood, metals, and glass.

2) The carbon flux of the fossil fuel consumption associated with the MSW collection and transportation system includes the horizontal carbon flux (fossil fuel consumption, calculated by Eq. (2)) and the vertical carbon flux (the carbon emission of fossil fuel burning). The fossil fuel used in the studied MSWM system was diesel, and the average diesel consumption for waste transportation was obtained from the basic indicators of the MSW transporting vehicles. When we calculated the vertical carbon flux of fossil fuel burning, we assumed that all of the carbon in the diesel was transformed to gaseous material and released to the air.

$H C_{\text {diesel }}=\sum M_{i} \cdot P_{\text {transport }} \cdot D \times c_{\text {diesel }} \times \rho_{\text {diesel }}$

where $H C_{\text {gasoline }}$ is the horizontal carbon flux of the gasoline input for the municipal solid waste management system; $M$ is the weight of the municipal solid waste production per year; $i$ is the studied year; $P_{\text {transport }}$ is the average diesel consumption for waste transportation, $0.022 \mathrm{~L}$ ton $\mathrm{Mg}^{-1} \mathrm{~km}^{-1} ; D$ is the average transportation distance of the municipal solid waste from the city center to the landfill, $17 \mathrm{~km}$; $c_{\text {diesel }}$ is the carbon content of the diesel, $86.86 \%$; and $\rho_{\text {diesel }}$ is the density of the diesel, $0.85 \mathrm{~kg} \mathrm{~L}^{-1}$.

\subsection{Carbon cycles of different MSWM systems}

\subsubsection{Landfill}

1) Carbon flux of landfill gases

The vertical carbon flux of landfill gases was simulated and calculated using the Landfill Gas Emissions Model (LandGEM) Version 3.02 (USEPA, 2005), which was developed by the US Environmental Protection Agency (USEPA) in 2005. Eq. (3) shows the calculation model by LandGEM. LandGEM uses a first-order decomposition rate equation to estimate annual emissions over a given time period. The data that are required for the LandGEM model were collected from local MSWM authorities, e.g., the annual disposed MSW, average temperature, climate, type of landfill, etc.

$Q_{\mathrm{CH}_{4}}=\sum_{i=1}^{n} \sum_{j=0.1}^{1} k L_{0}\left(\frac{M_{i}}{10}\right) e^{-k t_{i j}}$

where $\quad Q_{\mathrm{CH}_{4}}=$ annual methane generation in the year of the calculation ( $\mathrm{m}^{3} /$ year); $i=1$-year time increment; $n=$ (year of the calculation $)$ - (initial year of waste acceptance); $j=0.1$-year time increment; $k=$ methane generation rate $\left(\right.$ year $\left.^{-1}\right) ; L_{0}=$ potential methane generation capacity $\left(\mathrm{m}^{3} / \mathrm{Mg}\right) ; M_{i}=$ mass of waste accepted in the $i$ th year $(\mathrm{Mg})$; and $t_{i j}=$ age of the $j$ th section of waste mass $M_{i}$ accepted in the $i$ th year (decimal years). $L_{0}$ and $k$ were determined when the characteristics of the studied landfill was input to the LandGEM model, e.g., the region of landfill is located (cold and wet region in China), past subsurface fires (no past surface fires), the average depth (more than $10 \mathrm{~m}$ ), etc. The recommended values of $L_{0}$ and $k$ are $56 \mathrm{~m}^{3} / \mathrm{Mg}$ and 0.11 year $^{-1}$. 


\section{2) Landfill carbon stocks}

In this case, all of the municipal solid waste generated from Jingmen City was collected and transported to the Yingchun landfill. The methods of field investigation, sampling and lab analysis were applied to study the carbon stocks in terms of landfilled stored waste. The biological and chemical processes of the municipal solid waste in a landfill are influenced by multiple factors, such as waste composition, temperature, rain and landform; therefore, exercises of field research and lab analysis are necessary for studying the carbon stocks. The stored waste that was still present in the landfill was estimated to be approximately 501,000 tons $\left(551,000 \mathrm{~m}^{3}\right)$, as estimated by the present elevations of the surface of the landfill dump, compared to the historic base elevation data, and as calculated from the stored waste using the grid method $(100 \mathrm{~m} \times 100 \mathrm{~m})$. Stored solid waste was sampled using a drilling machine equipped with a $12-\mathrm{cm}$ drill bit at nine grid locations. The sampling was initiated after approximately $50 \mathrm{~cm}$ of the surface cover soil was removed and continued downwards every $6 \mathrm{~m}$ until the original bottom clay was detected. In total, 22 samples were collected from different landfill layers, and each sample weighed approximately $50 \mathrm{~kg}$. Each sample was first fully mixed, quartered twice or three times on a plastic cloth, and then passed through a $10-\mathrm{mm}$ sieve; the undersized parts were referred to as soil-type materials and sealed for further chemical analysis. The average composition of disposed solid waste collected in the Yingchun landfill was weighed and analyzed. We measured the total carbon (TC) for the soil-like materials and the plastics, and the TC contents for the other components were obtained from a previous study (Tchobanoglous, 2000). The total carbon (TC) content of the soil-like material samples was determined using an element analyzer (Model Vario EL III), and the TC of plastic waste was determined with a field emission scanning electron microscope (Model SU-8020, produced by Hitachi, Japan).

\subsubsection{Incineration}

The carbon cycle of municipal solid waste incineration is represented by Eq. (4). Considering the carbon cycling, we assumed that the main carbon emission to the air was carbon dioxide, and the other carbon element was stocked in the incineration bottom ash and fly ash. The carbon content data of a typical municipal solid waste incineration plant were chosen as the reference data of the study scenario, where the total carbon (TC) was $26.3 \mathrm{~g} \mathrm{~kg}^{-1}$ and the organic carbon was $17.0 \mathrm{~g} \mathrm{~kg}^{-1}$ (Liu et al., 2013). MSW incineration bottom is a type of industrial waste, and fly ash is a type of hazardous waste; both of these need to be disposed of in landfills, and they therefore form new carbon stocks.

$\mathrm{MSW}+\mathrm{O}_{2} \stackrel{\text { incineration }}{\longrightarrow} \mathrm{CO}_{2}+\mathrm{H}_{2} \mathrm{O}+\mathrm{SO}_{2}+$ ash

\subsubsection{Compost}

The carbon cycle of municipal solid waste compost is represented by Eq. (5). With a view on carbon cycling, we assumed that all organic carbon is biologically degraded into carbon dioxide and compost (including new bacteria cells, resistant organic matter) and that all of the inorganic carbon remains in the compost. The carbon biological degradation (transformed into carbon dioxide) rate of compost is $67 \%$, while the rate of remaining carbon in the compost is 33\% (Haug, 1993).

Organic waste $+\mathrm{O}_{2}$

$\stackrel{\text { aerobic compost }}{\longrightarrow} \mathrm{CO}_{2}+\mathrm{H}_{2} \mathrm{O}+\mathrm{NH}_{3}+\mathrm{SO}_{4}^{2-}+$ compost

\subsubsection{Scenario design}

Three scenarios were designed to analyze the carbon cycle of different MSWM systems. Scenario 1 (landfill/LF): business as usual scenario, where all of the MSW generated by Jingmen City is transported to the landfill, and the landfill does not have LFG collection or a treatment system. Scenario 2 (incineration/INC): all of the MSW generated by Jingmen City is transported to the incineration plant, and the bottom ash is transported to the landfill for further disposal. Scenario 3 (source separation and integrated technologies/SIT): a sound household separation system is established, and MSW is separated into categories including food waste, combustible waste (plastic waste, paper, textile and wood) and recyclables (ash and stone, glasses, metals). Furthermore, food waste is treated in the compost plant, combustibles are treated and converted to recovered energy in an incineration plant, ash and stone are treated to become regenerated constructing materials, and glasses and metals are transported to the material recovery factories in the urban system.

\section{Results}

\subsection{Horizontal carbon flux of MSW input}

The annual horizontal carbon flux of the MSW input is shown in Fig. 2. The total horizontal carbon flux of MSW input from 1989 to 2004 was $293.47 \mathrm{Gg}$, and the horizontal carbon flux values of each MSW component were as follows: food waste, $130.98 \mathrm{Gg}$; ash and stone, $99.73 \mathrm{Gg}$; paper, $18.98 \mathrm{Gg}$; textile, $20.16 \mathrm{Gg}$; plastic, $22.55 \mathrm{Gg}$; wood, $0.72 \mathrm{Gg}$; metal, $0.28 \mathrm{Gg}$; and Glass, $0.08 \mathrm{Gg}$. Moreover, food waste input accounted for $44.6 \%$ of the total horizontal carbon flux and ranked first among all of the waste components. The horizontal carbon flux of the MSW input increased from $3.06 \mathrm{Gg}$ to $36.93 \mathrm{Gg}$ between 1989 and 2004, and it increased 12.07 times. The reason for this trend is that the total generation quantity of MSW increased from 18.3 thousand tons to 180.0 thousand tons, an increase of 9.84 times. Moreover, the MSW components with higher carbon content and lower moisture content also increased; for example, ash and stone (carbon content $=0.263 \mathrm{~g} / \mathrm{g}$ ), textile (carbon content $=0.55 \mathrm{~g} / \mathrm{g}$ ) and plastic waste $($ carbon content $=0.60 \mathrm{~g} / \mathrm{g})$ increased by $36.57,3.11$ and 36.13 times between 1989 and 2004.

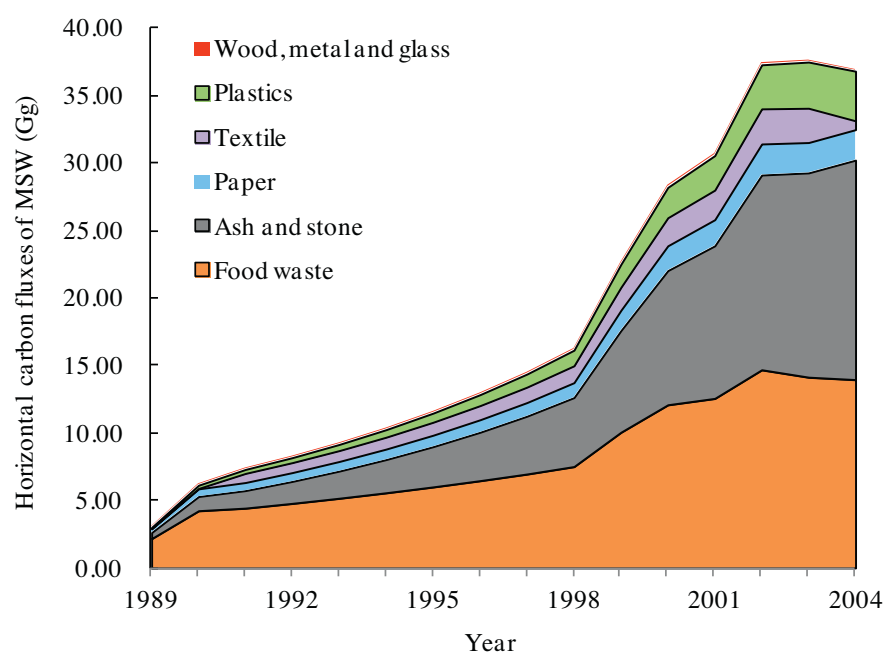

Fig. 2. Horizontal carbon flux of the municipal solid waste management system in Jingmen City. From the years 1989 to 2004. 


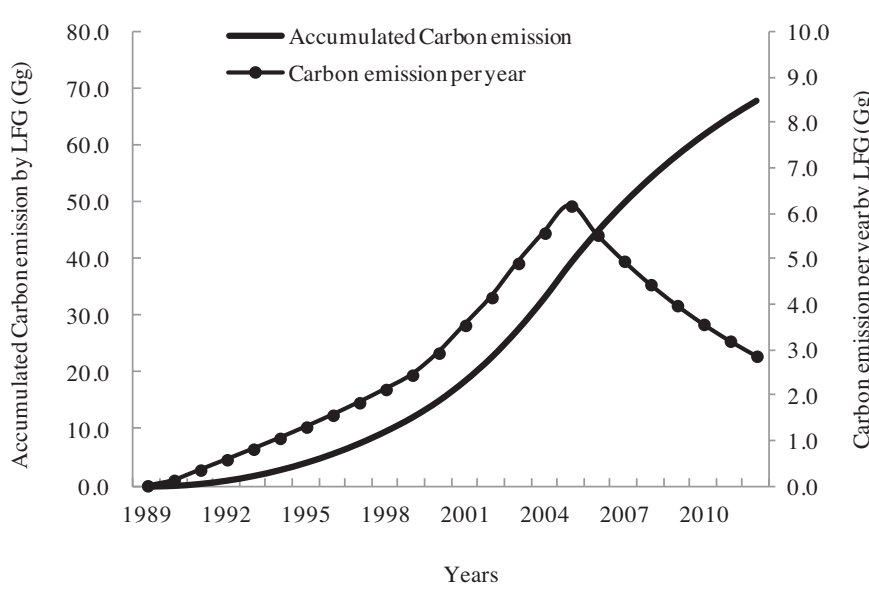

Fig. 3. Carbon emissions via landfill gas in the Yingchun landfill, Jingmen City. From the years 1989 to 2012 .

\subsection{Carbon flux of waste collection and transportation}

MSW collection and transportation is part of the MSW management system, but it is also a very important factor for considering carbon flux. The fossil fuel input to the MSW collection and transportation system is the horizontal carbon flux, while the carbon emission from the consumption and burning of fossil fuel during the process of MSW collection and transportation is the vertical carbon flux. The horizontal and vertical flux values of waste collection and transportation were estimated based on the MSW generation and the number of vehicles that were used in the MSW management systems. The total municipal solid waste generation was 1452.6 thousand tons from the years 1989 to 2004, and the average transportation distance was $17 \mathrm{~km}$. According to these data, the horizontal and vertical carbon flux was $1.37 \mathrm{Gg}$.

\subsection{Carbon flux and stocks of the landfill}

\subsubsection{Vertical carbon flux of landfill gas}

The quantity of landfill gas was simulated and calculated by the LandGEM model, and the annual and accumulated carbon flux in terms of landfill gas is shown in Fig. 3. The landfill gases (LFGs) of the Yingchun landfill increased from the year 1989 on, when MSW began to be disposed of in the landfill; the LFG emission reached its peak value in the year 2005 (11.05 million $\mathrm{m}^{3} /$ year, one year after landfill closure) and then decreased. In the year 2012, the LFGs decreased to 5.11 million $\mathrm{m}^{3} /$ year, almost half of the peak value. According to the simulation, the accumulated vertical carbon flux from 1989 to 2012 was $67.87 \mathrm{Gg}$, and it increased from $0.12 \mathrm{Gg} /$ year to $6.17 \mathrm{Gg} /$ year from 1989 to 2005 . The accumulated vertical carbon flux throughout the operating period of the landfill (years 1989 to 2004 ) was $33.22 \mathrm{Gg}$, which accounted for $48.9 \%$ of the total carbon emission in forms of LFGs.

\subsubsection{Carbon stocks of the landfill}

The carbon stocks of different components of stored wastes in the Yingchun landfill are shown in Fig. 4, and the field study was completed in July 2012. According to the sampling and field studies, the average composition of stored solid waste in the Yingchun landfill was soil-type materials ranked first $(75.02 \pm 6.83 \%)$, followed by plastic $(10.62 \pm 5.12 \%)$, and then stone $(8.26 \pm 4.12 \%)$, and the proportions of wood and bamboo, textiles, glass, metal and paper were $2.43 \pm 1.50 \%, 1.49 \pm 1.31 \%, 0.64 \pm 0.40 \%, 0.41 \pm 0.44 \%$ and $0.15 \pm 0.35 \%$, respectively. Other waste, which was difficult to recognize, accounted for $0.98 \pm 1.28 \%$. According to the test results of the surface elevations and the bottom elevations of

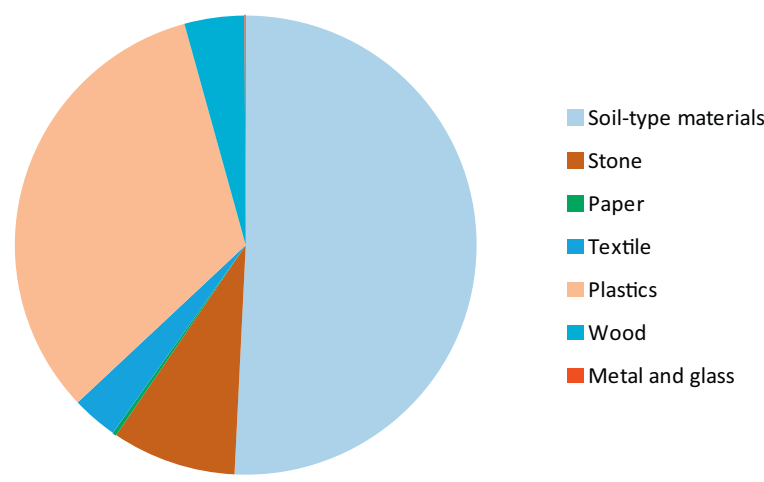

Fig. 4. Carbon stocks of different components of municipal solid waste in the Yingchun landfill, Jingmen City, from 1989 to 2012.

the landfill dump, the total quantity of stored waste in Yingchun landfill was 501 thousand tons. The carbon stocks in the Yingchun landfill amounted to $114.58 \mathrm{Gg}$, composed of the following: soil-type materials, $58.18 \mathrm{Gg}$; stone, $10.01 \mathrm{Gg}$; paper, $0.31 \mathrm{Gg}$; textile, $3.70 \mathrm{Gg}$; plastic waste, $37.46 \mathrm{Gg}$; wood, $4.82 \mathrm{Gg}$; metal, $0.09 \mathrm{Gg}$; and glass, $0.02 \mathrm{Gg}$. The carbon stocks in terms of soil-like materials and plastic waste ranked first and second among all of the components of stored wastes and accounted for $50.78 \%$ and $32.69 \%$, respectively. The organic carbon stock in the soil-like materials was $26.33 \mathrm{Gg}$, which accounted for $22.98 \%$ of the total carbon stocks and could have great potential to supply new organic carbon sources to the urban system in the way of landfill mining, stored waste separation and farm land recycling.

\subsection{Carbon cycles of MSWM systems}

The carbon flows, fluxes and stocks of different MSWM systems are shown in Fig. 5. Fig. 5(A-C) shows the carbon cycles under different scenarios LF, INC, SIT, respectively. In LF, the vertical carbon flux to the atmosphere was $69.24 \mathrm{Gg}$, the vertical carbon to the leachate and soil was $111.02 \mathrm{Gg}$, and $39.04 \%$ of the carbon was stocked in the landfill. The vertical carbon flux to the atmosphere of LF was small compared to INC and SIT, but in LF, $35.01 \mathrm{Gg}$ of carbon was emitted in the form of methane, which had 21 times the global warming potential of carbon dioxide. LF had the largest quantity of carbon stocks among all of the scenarios because the biological and chemical processes were slower than incineration and composting; moreover, the inert parts of MSW, such as plastic waste, stone, and glass are very slow to biodegrade inside the landfill. The carbon flux of LF will thus resist changing for a very long time after the landfill closure. According to the simulation of the LandGEM model, the landfill gas emission rate will be less than $1 \mathrm{~m}^{3} / \mathrm{min}$ in the year 2039 and will completely stop generating landfill gas in the year 2077 .

In INC, most of the carbon was thermally degraded into carbon dioxide ( $286.97 \mathrm{Gg}$, accounting for $97.3 \%$ ) and emitted to the atmosphere. Although INC could recover energy through the thermal degradation process, it also wasted a lot of potential carbon sources of biogenic carbon and fossil carbon, which could be helpful to human society and the urban system. However, INC had great potential for waste reduction and only formed a carbon stock of $7.87 \mathrm{Gg}$ in the landfill. In the SIT scenario, the carbon emission to the atmosphere had the smallest global warming potential and no carbon was stocked in the MSWM system. There were two horizontal carbon fluxes from the MSWM system to the urban system, which means that the MSWM system provided regenerated carbon sources to human society. The compost plant recycled $43.22 \mathrm{Gg}$ of carbon to farm land and green land, and the reverse logistics could send back $100.08 \mathrm{Gg}$ carbon to the urban system for further 


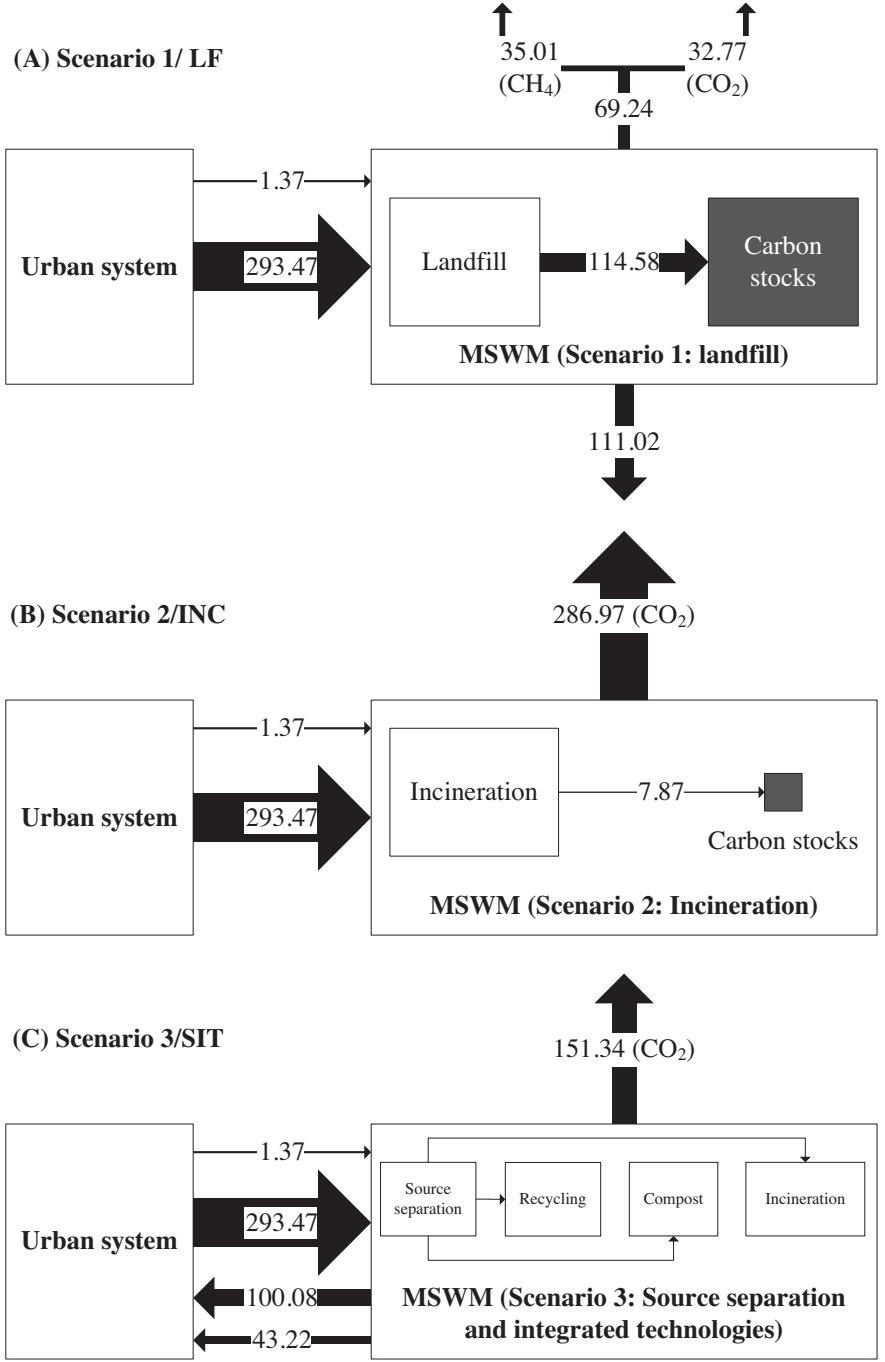

Fig. 5. The carbon cycle of the municipal solid waste management system in Jingmen City (waste input from 1989 to 2004).

material recovery. This means that the SIT is potentially more ecologically efficient than LF and INC from the perspective of urban carbon cycling and metabolism. However, IF and INC also have potential to provide a carbon source to the urban system due to the application of innovative technology. For example, enhanced landfill mining could recycle soil-like materials to green land, and it could also recover the carbon as fossil fuels (plastic wastes, wood, etc.) (Krook, 2010); in addition, the incineration bottom ash could be recycled as constructing materials (e.g., regenerated bricks).

\section{Discussion}

The quantity of carbon flux of the MSWM system does not have an effect as great as that of energy consumption, transportation and building on urban metabolism (Chen et al., 2013). Case study of the urban carbon cycle of Nanjing City showed that carbon flux in terms of solid waste was 43.31-79.48 Gg (2000-2009), which was only $0.25-0.3 \%$ of the total carbon flux in the city (including industrial and residential carbon flux) (Zhao et al., 2014). However, the solid waste became a more important element of the carbon flux on the neighborhood scale. It was revealed that the carbon export brought by garden waste, human waste, food waste and other waste was $13.4 \%$ of the total carbon export (Kellett et al., 2013). In previous studies of the urban carbon cycle and urban metabolism, the
MSWM system was not given sufficient attention, mainly because of the inadequate data in this field. Nevertheless, the main carbon emission of the MSWM system is in the form of methane under an incomplete facility and bad operation, therefore, MSW could also play an important role and thus cannot be ignored when we analyze urban carbon cycling. For instance, much more methane will be produced and emitted to the atmosphere when the MSW treatment facility consists of open dumps or landfills without either gas flaring or electricity production (Couth and Trois, 2011).

Municipal solid waste was classified as a type of carbon flux that is exported out of the cities; nevertheless, MSW was not exported out of the city but imported to the sectors of the MSWM systems inside the city (incinerator, compost plant, recycling center, landfill, etc.) in many cases (as described in Fig. 1). Some studies have focused on the carbon emission of MSW treatment facilities (He et al., 2011), but few studies have considered it on the basis of carbon cycling. In this study, we found that $43.22 \mathrm{Gg}$ of carbon and $100.08 \mathrm{Gg}$ of carbon could be recycled to urban ecosystem (farm land, green land and recovery industries) through compost facilities and reverse logistics. MSWM could also play an important role of supplying new carbon sources to the urban areas. MSWM is a system that could be integrated as a city subsystem when doing city-level analysis, and could be compared with the carbon fluxes of other subsystems such as building, energy consumption, transportation, etc. MSWM is a self-organized system that includes the technology, facilities, governance and management, and could significantly affect urban carbon cycling. Thus, more attention should be focused on the carbon fluxes and carbon stocks of MSWM systems for a much more comprehensive understanding of urban carbon cycling.

The MSWM system is not independent from the urban system but is rather an indispensable part of the urban system, and the technological facilities, governance and management of the city affect the carbon cycle (Chen and Lin, 2008; Mühle et al., 2010). In this study, we found that incineration release largest vertical carbon emissions, while landfill formed largest carbon stocks and GHGs emissions. Previous studies also showed that the highest carbon emission was from using a sanitary landfill without either gas flaring or electricity production, and this case was worse than the case using waste open dumpsites. Landfills with either flaring or energy production from the collected gas both produced similar positive carbon emissions. Composting and anaerobic digestion were the two best options, with composting being carbon neutral and digestion being carbon negative (Barton et al., 2008). Though there is still uncertainty about whether MSW incineration creates a carbon source or a carbon sink, the objective point is that the MSW incinerations with electricity/heat recovery and management improvement (e.g., source separation and mechanical-biological pretreatment) could potentially operate as carbon sinks; otherwise, incinerations of the mixed waste with high moisture content or without electricity/heat recovery could be carbon sources (Papageorgiou et al., 2009; He et al., 2011; Kuo et al., 2011). The carbon cycling will be different from that of MSWM systems, which have a different level of technology, facilities, governance and management of MSW collection (with or without source separation), routine and distance of MSW transportation, material recycling and energy recovery, etc. (Bastin and Longden, 2009; Calabrn, 2009; Couth and Trois, 2010). This study also shows that the SIT scenario has much more efficient carbon cycling structure than other scenarios. Technological and management upgrading of MSWM systems could reduce the input carbon flux, decrease the carbon emission, and recycle the recovered carbon resources to the urban systems via methods such as source separation, decentralized compost, optimization of collection and transportation routine, methane collection and landfill energy recovery, mechanical-biological pretreatment before 
incineration, food waste digestion, enhanced landfill mining, etc.

The studied case Jingmen city could be representative of other cities in China, because the collecting and disposal models are very similar and the average landfill rate is $73.4 \%$ in 2012 around all Chinese cities. However, most Chinese cities are also undergoing rapid urbanization as Jingmen city, the quantity, components, technical and managing model of MSW were kept changing in recent years. For example, much more demolition wastes were generated due to rapid urbanization, while inhabitants tended to throw away much more textile and plastic material with an increase in average income. It will significantly affect the carbon cycling of MSWM systems in Chinese cities. In technology and management aspects, the Chinese governors are increasing the investments on incineration and source separation, which may also change the carbon cycles of MSWM system in the future, as the result of our scenarios analysis. Rising attentions had been paid on GHGs emissions and global climate change, thus the conceptual carbon model could be well integrated into MSWM decision support tools, and may play an important role for optimizing the MSWM systems. However, the formulating models and local parameters were needed to be collected to improve the carbon cycling model of MSWM systems.

\section{Conclusion}

This study has established a conceptual carbon cycling model that could be applied for analyzing carbon fluxes, stocks and flows of MSWM systems. Field studies and scenario analysis indicated that landfill is not only a source of carbon flux, but also a potential important carbon stock in urban ecosystem, and the stocked carbon could be supplied to the urban ecosystem by landfill mining. Incineration transforms most of the carbon embedded in the MSW into vertical fluxes of carbon dioxide. Technological integration and management innovation could change the structure of carbon cycling of MSWM systems. Waste minimization, source separation, recycling, and the improvement and integration of waste treatment technologies can optimize the carbon cycle with regard to urban metabolism.

\section{Acknowledgements}

This study was financially supported by the National Natural Science Foundation of China (41201579) and the National Key Technology R\&D Program during the Twelfth Five-year Plan Period of the Ministry of Science and Technology of China (2012BAC13B04). This work was also partially supported by the Environmental Sanitation Agency of Jingmen City. Thanks are also due to the reviewers who helped us to improve the paper.

\section{References}

Barton, J.R., Issaias, I., Stentiford, E.I., 2008. Carbon - making the right choice for waste management in developing countries. Waste Manage. 28, 690-698.

Bastin, L., Longden, D.M., 2009. Comparing transport emissions and impacts for energy recovery from domestic waste (EfW): centralised and distributed disposal options for two UK Counties. Comput. Environ. Urb. Syst. 33, 492-503.

Beigle, P., Lebersorger, S., Salhofer, S., 2008. Modelling municipal solid waste generation: a review. Waste Manage. 28, 200-214.

Calabrn, P.S., 2009. Greenhouse gases emission from municipal waste management: the role of separate collection. Waste Manage. 29, 2178-2187.

Chai, X., Lou, Z., Takayuki, S., Hirofumi, N., Zhu, Y., Cao, X., Teppei, K., Toshio, I., Zhao, Y., 2010. Characteristics of environmental factors and their effects on $\mathrm{CH}_{4}$ and $\mathrm{CO}_{2}$ emissions from a closed landfill: an ecological case study of Shanghai. Waste Manage. 30, 446-451.

Chen, T., Lin, C., 2008. Greenhouse gases emissions from waste management practices using Life Cycle Inventory model. J. Hazard. Mater. 155, 23-31.
Chen, G.Q., Guo, S., Shao, L., Li, J.S., Chen, Z.M., 2013. Three-scale input-output modeling for urban economy: carbon emission by Beijing 2007. Commun. Nonlinear Sci. Numer. Simul. 18, 2493-2506.

Chen, G.Q., Shao, L., Chen, Z.M., Li, Z., Zhang, B., Chen, H., Wu, Z., 2011a. Low-carbon assessment for ecological wastewater treatment by a constructed wetland in Beijing. Ecol. Eng. 37, 622-628.

Chen, S., Chen, B., 2012. Network environ perspective for urban metabolism and carbon emissions: a case study of Vienna, Austria. Environ. Sci. Technol. 46, 4498-4506.

Chen, X., Xi, F., Geng, Y., Fujita, T., 2011b. The potential environmental gains from recycling waste plastics: simulation of transferring recycling and recovery technologies to Shenyang, China. Waste Manage. 31, 168-179.

Couth, R., Trois, C., 2010. Carbon emissions reduction strategies in Africa from improved waste management: a review. Waste Manage. 30, 2336-2346.

Couth, R., Trois, C., 2011. Waste management activities and carbon emissions in Africa. Waste Manage. 31, 131-137.

Fdez-Güelfo, L.A., Álvarez-Gallego, C., Sales, C., Romero García, L.I., 2012. Drythermophilic anaerobic digestión of organic fraction of municipal solid waste: methane production modeling. Waste Manage. 32, 382-388.

Galina, C., 2008. Modeling the carbon cycle of urban systems. Ecol. Model. 216 107-113.

Gunalay, Y., Yeomans, J.S., Huang, G.H., 2012. Modelling to generate alternative policies in highly uncertain environments: application to municipal solid waste management planning. J. Environ. Inform. 19, 58-69.

Haug, R.T., 1993. The Practical Handbook of Compost Engineering. Lewis Publishers, Boca Raton, USA.

He, P.J., Chen, M., Yang, N., Shao, L.M., 2011. GHG emissions from Chinese MSW incineration and their influencing factors - case study of one MSW incineration plant in Shanghai, China. Environ. Sci. 31, 402-407.

IPCC, 2007. Guide lines for National Greenhouse Gas Inventories: Reference Manual.

Kellett, R., Christen, A., Coops, N.C., van der Laan, M., Crawford, B., Tooke, T.R., Olchovski, I., 2013. A systems approach to carbon cycling and emissions modeling at an urban neighborhood scale. Landsc. Urb. Plan. 110, 48-58.

Kennedy, C., Cuddihy, J., Engel-Yan, J., 2007. The changing metabolism of cities. J. Ind. Ecol. 11, 43-59.

Khoo, H.H., Lim, T.Z., Tan, R.B.H., 2010. Food waste conversion options in Singapore: environmental impacts based on an LCA perspective. Sci. Total Environ. 408 1367-1373.

Kollikkathara, N., Feng, H., Yu, D., 2010. A system dynamic modeling approach for evaluating municipal solid waste generation, landfill capacity and related cost management issues. Waste Manage. 30, 2194-2203.

Krook, J., 2010. Urban and landfill mining: emerging global perspectives and approaches. J. Clean. Prod. 18, 1772-1773.

Kumar, S., Mondal, A., Gaikwad, S., Devotta, S., Singh, R., 2004. Qualitative assessment of methane emission inventory from municipal solid waste disposal sites: a case study. Atmos. Environ. 38, 4921-4929.

Kuo, J.H., Lin, C.L., Chen, J.C., Tseng, H.H., Wey, M.Y., 2011. Emission of carbon dioxide in municipal solid waste incineration in Taiwan: a comparison with therma power plants. Int. J. Greenh. Gas Control 5, 889-898.

Lebel, L., 2005. Carbon and water management in urbanization. Global Environ. Change 15, 293-295.

Li, J.S., Chen, G.Q., Lai, T.M., Ahmad, B., Chen, Z.M., Shao, L., Ji, X., 2013. Embodied greenhouse gas emission by Macao. Energy Policy 59, 819-833.

Liu, K., Lin, J., Bao, L., Cao, L., Zeng, J., Wang, G., Long, S., Li, Y., 2013. Research of organic carbon components in MSWI. Chin. Environ. Sci. Technol. 36, 95-99 (in Chinese).

Mühle, S., Balsam, I., Cheeseman, C., 2010. Comparison of carbon emissions associated with municipal solid waste management in Germany and the UK. Resour. Conserv. Recycl. 54, 793-801.

Papageorgiou, A., Barton, J., Karagiannidis, A., 2009. Assessment of the greenhouse effect impact of technologies used for energy recovery from municipal waste: a case for England. J. Environ. Manage. 90, 2999-3012.

Pires, A., Martinho, G., Chang, N.B., 2011. Solid waste management in European countries: a review of system analysis techniques. J. Environ. Manage. 92, 1033-1050.

Svirejeva-Hopkins, A., Schellnhuber, H.J., 2006. Modelling carbon dynamics from urban land conversion: fundamental model of city in relation to a local carbon cycle. Carbon Balance Manage. 1, 1-8.

Svirejeva-Hopkins, A., Schellnhuber, H.J., 2008. Urban expansion and its contribution to the regional carbon emissions: using the model based on the population density distribution. Ecol. Model. 216, 208-216.

Tchobanoglous, G., Theisen, H., Vigil, S., 2000. Integrated Solid Waste Management: Engineering Principles and Management Issues. McGraw-Hill, New York.

US EPA, 2005. LMOP Developed the China Landfill Gas (LFG) Model. http://www.epa. gov/lmop/international/tools.html\#a02

US EPA, 2012. Global Anthropogenic Non- $\mathrm{CO}_{2}$ Greenhouse Gas Emissions 1990-2030, http://www.epa.gov/climatechange/Downloads/EPAactivities/ MAC_Report_2013.pdf (accessed 03.08.14)

Wolman, A., 1965. The metabolism of cities. Sci. Am. 213, 179-190.

Zhao, R., Huang, X., Zhong, T., Liu, Y., Chuai, X., 2014. Carbon flow of urban system and its policy implications: the case of Nanjing. Renew. Sustain. Energy Rev. 33, 589-601.

Zhou, C., Liu, J., Wang, R., Yang, W., Jin, J., 2011. Exergetic assessment of municipa solid waste management system in south Beijing. Ecol. Complex. 7, 162-169. 